\title{
EDITORIAL
}

\section{Realism and utopianism}

\author{
H. L. W E S S E L I N G*
}

Ten years ago, in 1988, the then Prime Minister Margaret Thatcher delivered her famous Bruges Speech. In this, among other things, she said the following:

To try to suppress nationhood and concentrate power at the centre of a European conglomerate would be highly damaging and would jeopardise the objectives we seek to achieve.

Europe will be stronger precisely because it has France as France, Spain as Spain, Britain as Britain, each with its own customs, traditions and identity. It would be folly to try to fit them into some sort of identikit European personality.

Some of the Founding Fathers of the Community thought that the United States of America might be its model, but the whole history of America is quite different from Europe. People went there to get away from the intolerance and constraints of life in Europe. They sought liberty and opportunity and their strong sense of purpose has, over two centuries, helped to create a new unity and pride in being American, just as our pride lies in being British or Belgian or Dutch or German.

When saying this she was, of course, simply echoing what General de Gaulle had said nearly 30 years earlier at an equally famous press conference.

I do not believe that Europe can be a living reality if it does not encompass France with her French, Germany with her Germans, Italy with her Italians and so on. Dante, Goethe, Chateaubriand do belong to the whole of Europe for the very reason that they were pre-eminently Italian, German and French. They would not have meant so much for Europe if they had been apatrides and had thought and written in some sort of 'integrated' Esperanto or Volapük.

De Gaulle later repeated the same message in a television interview with Michel Droit in which he said:

Of course we can jump on our chairs and dance and shout Europe! Europe! Europe!', but that does not mean anything and it does not bring us anywhere. Therefore I say once more: We have to take things as they are. How they are? There is a nation France. This cannot be denied. It exists. There is a nation Germany. This cannot be denied. It exists. There is a nation Italy, a nation Belgium, a nation Holland and, somewhat further away, a nation England and a nation Spain. Nations they are. They have their history, they have their language, they have their way of life.

Both statesmen were right. The creation of the Common Market, the European Community and even the European Union has not brought about the end of the nation-state. We cannot really imagine a Europe in which there would no longer be a Germany, a France or a Holland. The idea of a process in Europe following the same pattern as that which led to the creation of the United States is clearly an illusion. As the former German Chancellor Helmuth Schmidt wrote some years ago in an article in Die Zeit: 'It is about time to finally recognize that Charles

* NIAS, Meijboombaan 1, 2242 PR Wassenaar, The Netherlands. 
de Gaulle was right with his concept of a Europe des patries'. Now, De Gaulle never used the term l'Europe des patries. He actually said l'Europe des Etats, which is indeed more correct, although such nuances are not very important in this context. What all three politicians intended to say is that the original federalist approach to Europe was an illusion. And in this they are undoubtedly right.

Thus, at first sight, it looks as if the federalists are the utopianists and the nationalists are the realists. Although this is true, it is not the entire truth. Nations and states are indeed entities. They exist. But they have not always existed. They are not the products of nature but of history. Nations are 'imagined communities', to use the elegant phrase formulated by Benedict Anderson, that is to say: creations of the mind.

It is interesting to note that General de Gaulle and Mrs Thatcher spoke of the British, the French etc, each with their own language, history and way of life, thus suggesting that these are uniform and homogenous groups. But they could also have spoken of Britain with her Scots, Welsh, English and Irish or of France with her Bretons, Alsacians, Basques and others. These groups also have their own language, history and way of life. This, however, does not prevent them from forming together the British or the French nation and living together in one state, the United Kingdom and France respectively.

This combination of state and nation is what we call the nation-state and this nation-state is a typical European product which, for better or for worse, has been exported all over the world. In some cases, in the early states, like for example Britain, France and Spain, the state preceeded the nation. In other states, those of the latecomers, like Germany and Italy, the idea of a German and Italian nationhood preceded the process of forming a German and Italian state. In the first case historians speak of state-nations, in the second one of culture-nations. But, in whatever order things took place, in both cases a great deal of this feeling of nationhood was artificially put into the citizens' heads in the 19th century in order to make them better and more obedient citizens. In both cases also the outcome was the same: one form of social organization, the national one, overshadowed all other forms. This process culminated in the two World Wars of the 20th century. State formation, nationalism, interstate rivalry and war are part and parcel of European history.

Thus the realists are right when they emphasize the fundamental difference in history and development between Europe and the United States of America. But they are wrong when they suggest that nations are products of nature and therefore are bound to be with us forever. As the famous French writer Ernest Renan said more than a century ago: a nation is a product of the will. What makes a nation a nation, is the will to be a nation. This will was very strong in the 19th century, partly because of ideology but partly also because of the interest the citizens had in a strong state which provided them not only with security but also increasingly with social and economic advantages.

The nationalist ideology has lost much of its appeal after two World Wars, and the interest of the citizen in having a strong state has also diminished. The function of the state changed fundamentally after 1945, and two processes have been taking place in Europe since that time: decentralization and supranational integration. If these trends continue, the nation-states will also continue to lose many of their functions and there will be room for not just one, but for many social identities. To mention just one example, one could then be at the same time an Alsacian, Frenchman and European. 
Thus, unity does not necessarily imply uniformity, nor should it do so, because it is precisely the variations of national articulations and expressions that create the vitality of European civilization. This was already stated by the famous Dutch historian Johan Huizinga a long time ago. In an address to American students in 1924, Huizinga said the following.

I do not know whether Americans can fully realize the necessity there is for Europe of preserving its division into many nations, and the fervent desire of all and any of these to maintain their specific national existence. I do not mean this politically so much as culturally (...) It would be quite natural for you to say: why should not the European nations, after so many centuries of bitter strife, in the long run be merged into one vast unit? (...) Still, political harmony and concord is not the one thing the world stands in need of. However indispensable to civilization peace and order may be, real civilization is not contained in them. They may even be a danger to it, should they be promoted by equalizing and levelling. What we envy you is your unity, not your uniformity. We Europeans feel too keenly that no nation, however prosperous or great, is fit to bear the burden of civilization alone. Each in his turn is called upon in this wonderful world, to speak his word, and find a solution which just his particular spirit enabled him to express. Civilization is safeguarded by diversity. Even the smallest facets in the many-sided whole may sometimes catch the light and reflect it.

These words of Huizinga's sound rather romantic. But their basic assumption is shared by most of us, namely that Europe's historical greatness and present vitality arise from the fact that there are so many nations, each with its own cultural tradition. But at the same time we also know that, with all their differences they are all truly European and form some sort of community, although not necessarily a Union. Thus, the borderline between realists and utopianists is not really as clear cut as some would have us believe. 